\title{
Grazing, differential size-class dynamics and survival of the Mediterranean sponge Corticium candelabrum
}

\author{
Sònia De Caralt $^{1, *}$, María J. Uriz ${ }^{2}$, René H. Wijffels ${ }^{1}$ \\ ${ }^{1}$ Food and Bioprocess Engineering Group, Wageningen University, PO Box 8129, 6700 EV Wageningen, The Netherlands \\ ${ }^{2}$ Centre d'Estudis Avançats de Blanes (CEAB), Consejo Superior de Investigaciones Científicas (CSIC), \\ Accés a la Cala Sant Francesc 14, 17300 Blanes, Girona, Spain
}

\begin{abstract}
The growth dynamics and survival of the sponge Corticium candelabrum (Demospongiae: Homosclerophorida) were surveyed in the northwestern Mediterranean for more than 3 yr. Growth and regeneration rates, fission and fusion events and survival were monitored monthly. Moreover, in situ punctual clearance experiments were conducted seasonally searching for possible relationships between food uptake and sponge dynamics. The monthly growth rates (GR) of C. candelabrum were low $(0.19 \pm 0.02$ mean $[ \pm \mathrm{SE}]$ for the $3 \mathrm{yr}$ of study), variable and seasonal, with the highest values in summer. The cumulative survival function followed a stepped profile with several consecutive months without mortality separated by shorter mortality events, which mainly occurred in cold months (winter-spring). However, an event of high mortality ( $76 \%$ of the monitored individuals died) took place in the particularly warm summer 2003. Fission events were frequent after previous damage (e.g. partial predation) and only one fusion event was recorded along the study period. The diet of $C$. candelabrum was highly heterogeneous. Differences in clearance rates (CR) among picoplankton types with season indicated that the sponge retained with different efficiency the several picoplankton types present in the water. Survival and GRs were significantly different for small, medium and large individuals (size-classes I, II and III), with the small sponges showing the lowest survival (56.6\% cumulative mortality for the last $2 \mathrm{yr}$ of study) and the highest GRs $\left(0.18 \pm 0.03 \mathrm{mo}^{-1}\right.$, mean $\pm \mathrm{SE}$ ). On the whole, the results indicate that $C$. candelabrum is a slow-growing but dynamic sponge.
\end{abstract}

KEY WORDS: Growth · Shrinkage $\cdot$ Survival $\cdot$ Filtration $\cdot$ Fusion $\cdot$ Fission $\cdot$ Regeneration $\cdot$ Porifera

\section{INTRODUCTION}

Sponges are sessile filter-feeders, modular organisms with a reported plasticity that allows them to change their shape and size to accommodate environmental changes (e.g. Pansini \& Pronzato 1990, Garrabou \& Zabala 2001). Moreover, sponges are able to regenerate their tissues after damage (e.g. Jackson \& Palumbi 1979, Ayling 1983, Hoppe 1988, Leys \& Lauzon 1998, Turon et al. 1998, Wulff 2006), and thus they are among those modular organisms that can recover from partial mortality (reviewed in Henry \& Hart 2005).

Sponges often inhabit rocky bottoms where the substrate is crowded. As their growth is usually slow (e.g. Ayling 1983, Turon et al. 1998), they take benefit of their plasticity to compete for the space with other sessile, faster-growing organisms (e.g. Sebens 1987, Stocker 1991) by growing and/or de-growing along different zones of their perimeters. The growth dynamics of a sponge species is the result of integrating its own life history and its responses to envi- 
ronmental (biotic and abiotic) changes. Sponge dynamics involves growth, shrinkage, fission and fusion events. Data on sponge growth dynamics are basic in ecological and conservation issues such as capability to colonize new substrates, to compete with neighbors and to persist once installed, but also sponge growth dynamics may have an applied interest in the field of sponge culture for supplying biomass (e.g. for pharmaceutical companies searching for new drugs). Sponges under culture have been reported to show growth with no general trend (high inter-individual growth variability, e.g. Sipkema et al. 2006). Thus, understanding the dynamics and the food requirements of wild sponges is an essential first step to optimizing sponge growth in cultures.

To have a realistic overview of the general growth dynamics of a target sponge species, long-term studies (i.e. more than 1 biological cycle) should be conducted (e.g. Johnson 1979, Ayling 1983, Hoppe 1988, Pansini \& Pronzato 1990, Leys \& Lauzon 1998, Turon et al. 1998, Duckworth \& Batershill 2001, Garrabou \& Zabala 2001, Tanaka 2002). Moreover, in sponge monitoring, data should be recorded at short intervals and based on a large number of specimens, since studies encompassing low-frequency observations and/or performed on few specimens may fail to detect changes or general trends due to fast sponge dynamics (Leys \& Lauzon 1998) and large inter-individual variability (e.g. Pansini \& Pronzato 1990). Previous studies have demonstrated that sponge growth is extremely variable in time among individuals, which may be due to differences in individual fitness as a function of environmental factors (e.g. temperature, food availability and interaction with neighbors).

Regeneration is also decisive for sponge survival and persistence. The studies on sponge regeneration rates have mainly been addressed by assessing recovery after artificially induced injury (Jackson \& Palumbi 1979, Ayling 1983, Hoppe 1988, Leys \& Lauzon 1998, Turon et al. 1998). In contrast, few studies have monitored sponge recovery from natural damage after perturbation or predation (e.g. Wulff 2006), and none have been performed in the Mediterranean where the main factors affecting the regeneration processes (e.g. temperature, predator abundance, food and exosomatic energy entries) vary seasonally (Margalef 1985).

In the present study, we monitored monthly survival, growth, fusion, fission and regeneration rates of the sponge Corticium candelabrum Schmidt, 1862 for $3 \mathrm{yr}$. One of the main factors that determines growth rates (GR) in sessile invertebrates is food availability. To know whether the quality and quantity of food exert some influence on the growth dynamics of the sponge, the study of in situ clearance rates throughout the year was performed.

\section{MATERIALS AND METHODS}

Growth dynamics. The target species Corticium candelabrum is a common encrusting sponge with antimicrobial activity (De Caralt et al. 2003) widely distributed in the northwestern Mediterranean (Uriz et al. 1992). A total of 45 specimens of C. candelabrum ranging in area from 0.13 to $18.78 \mathrm{~cm}^{2}$ were labeled in a sublittoral area of the Blanes locality (northeast Spain, western Mediterranean, $2^{\circ} 48.12^{\prime} \mathrm{N}$, $\left.41^{\circ} 40.33^{\prime} \mathrm{E}\right)$. All the monitored individuals inhabited a rocky wall (25 $\mathrm{m}$ long) facing north, between 10 and $12 \mathrm{~m}$ deep, to minimize the possible effects of different environmental conditions on sponge dynamics.

After the first year of study, a high mortality event occurred (i.e. summer 2003), which reduced considerably the number of target specimens. Thus, in December 2003 a new set of individuals, ranging in area from 0.23 to $14.09 \mathrm{~cm}^{2}$, from the same zone, were included in the study to replace those that died.

During the study period, from September 2002 to December 2005, each labeled individual was photographed monthly and the sponge area was measured by image analysis (NIH Image program). From the pictures, mortality, depredation, fusion, fission, growth and recovery rates (RR) were computed.

A specimen was considered dead when it was missing from the sequential pictures. Predation was recognized with grazing marks and was recorded as a damaged area in a specimen that was healthy in the previous month. Recovery was computed when the damaged area healed. A fission event was computed when a single individual divided into 2 or more smaller new individuals that remained physically separated. A fusion event was computed when 2 close individuals became a single individual.

GR and RR were calculated with the following formula:

$$
\mathrm{GR}_{t}=\left[\left(\text { area }_{t+1}-\text { area }_{t}\right) / \text { area }_{t}\right] \times t^{-1}
$$

Since the measurements were done monthly, area is $_{t}$ the area in a given month, and area $_{t+1}$ is the area of the same individual in the next month.

Feeding experiments. Feeding experiments were carried out seasonally (4 times) in 2003 by incubating sponges in situ. Incubation chambers represent closed spaces in which we can measure food decrease in the water due to sponge feeding. Picoplankton constitutes the main part of the sponge diet (e.g. Reiswig 1971), since it is retained with the highest efficiency by sponges (Ribes et al. 1999). Therefore, we analyzed decreases in picoplankton (i.e. heterotrophic bacteria Synechococcus sp., Prochlorococcus sp. and picoeukaryotes) in the chambers after incubation. 
For the in situ incubations, entire specimens of Corticium candelabrum, similar in size, were carefully removed from their natural substrate (vertical rocky walls) and attached with a 2-component epoxy resin (IVEGOR ${ }^{\circledR}$ ) to horizontally placed tiles, in order to facilitate the emplacement and sealing of incubator chambers. The transplantation to tiles also allowed us to isolate the sponges from the rest of benthic organisms, which could interfere with the sponge filtration measurements. The tiles with the attached specimens were placed at $12 \mathrm{~m}$ depth in the sponge natural habitat and maintained there for sponge adaptation during 1 wk. Only healthy, actively filtering specimens were selected for the experiments.

Feeding experiments were conducted in 11 chambers $(\mathrm{N}=3)$ containing 1 specimen of Corticium candelabrum per chamber, following Cebrian et al. (2006). Three additional empty chambers were used to control possible increases or decreases in picoplankton due to factors other than sponge grazing, such as plankton division, mortality and sedimentation. Chambers were sealed to the tiles with epoxy resin in order to generate an isolated microenvironment. $5 \mathrm{ml}$ water samples from the chambers were taken at time 0 and $1 \mathrm{~h}$ later through a syringe connected to a $3 \mathrm{~mm}$ wide aperture. The narrow aperture remained closed until the moment the water sample was taken, which reduced to a minimum possible contamination from the external environment. Water samples were immediately fixed in a cocktail of paraformaldehyde and glutaraldehyde ( $1 \%$ and $0.05 \%$ respectively, final concentration) and kept cold in the dark. Once in the laboratory, the samples were frozen at $-80^{\circ} \mathrm{C}$ for posterior flow cytometer analysis. The specimens were removed from the tiles after the experiments, taken to the laboratory and placed in an oven at $90^{\circ} \mathrm{C}$ for $24 \mathrm{~h}$ to determine their dry weight (DW).

The water samples were analyzed for quantification of heterotrophic bacteria, cyanobacteria (i.e. Prochlorococcus sp. and Synechococcus sp.) and picoeukaryotes using flow cytometer (ACSCalibur, Becton Dickinson, $488 \mathrm{~nm}$ excitation laser flow) according to Gasol \& Moran (1999).

Just before processing, water samples were divided in 2 subsamples: 1 of $0.5 \mathrm{ml}$ (S1) to quantify the heterotrophic bacteria and another of $1 \mathrm{ml}$ (S2) to quantify the rest of the picoplankton. Then we added $150 \mu \mathrm{l}$ and $5 \mu \mathrm{l}$ to samples S1 and S2, respectively, of a stock precalibrated solution (Becton-Dickinson True-Count beads) containing fluoresbrite yellow-green beads (polysciences). The number of beads counted in each sample run was used to determine the sample volume processed and thus the cell abundance (density).

To separate different cell types, the Logical gating in Becton-Dickinson Cell Quest software was used. The small subsamples (S1) were treated with Syto 13 (Molecular Probes) at $2.5 \mathrm{\mu mol} \mathrm{l}^{-1}$, for staining the heterotrophic bacteria, and run at a flow rate of ca. $18 \mu \mathrm{l}$ $\min ^{-1}$. Heterotrophic bacteria were detected by their signature in a plot of side scatter versus green fluorescence. For quantification of Prochlorococcus sp., Synechococcus sp. and picoeukaryotes, the large subsamples (S2) were run at a flow rate of approximately

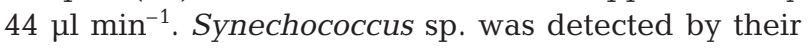
signature in a plot of orange versus red fluorescence. The signature for Prochlorococcus sp. was dark red instead of orange fluorescence, and picoeukaryotes had light red and no orange fluorescence.

Sponge clearance rates (CR) were calculated from the flow cytometer counts as decreases in picoplankton concentrations (cells ml $\mathrm{m}^{-1} t^{-1}$ ) in the water samples of each experimental chamber relative to the control chamber per unit time. Concretely, CR is the product of the amount of water being filtered $(\omega)$ and the amount of particles being retained from this water $(r)$ by the sponge:

$$
\mathrm{CR}=r \omega
$$

The basic equation modeling filtration is an exponential function of the form:

$$
\mathrm{C}_{t}=\mathrm{C}_{0} \times \mathrm{e}^{-r \times \omega \times \mathrm{DW} \times t / v}=\mathrm{C}_{0} \times \mathrm{e}^{-\mathrm{CR} \times \mathrm{DW} \times t / v}
$$

where $\mathrm{C}_{t}$ and $\mathrm{C}_{0}$ are the final and initial particle concentration, respectively, $v$ is the total volume of the incubation chamber $(1 \mathrm{l})$, and the $t$ is the time of the experiment $(1 \mathrm{~h})$.

Specific CRs were calculated as the volume of water cleared of each particle type (i.e. heterotrophic bacteria, Prochlorococcus sp., Synecoccocus sp. and picoeukaryotes) per unit time and sponge weight (ml swept clear $\mathrm{g} \mathrm{DW}^{-1} \mathrm{~h}^{-1}$ ).

CRs have also been called 'filtration rates' by several authors (e.g. Petersen \& Riisgard 1992) by assuming that the particles in the water are retained with $100 \%$ efficiency. However it has been reported that particles are retained by sponges with different efficiency depending on particle size (Turon et al. 1997). Thus, in our case, it is more consistent to consider that the volume of water passed through the aquiferous system per unit sponge weight and time was constant and that the several picoplankton types were retained with different efficiency (Turon et al. 1997, Ribes et al. 1999).

The total CR was calculated as the volume of water cleared of all types of particles present in the water in each season.

Statistical methods. To assess whether small and large sponges behaved differently, the target individuals were arbitrarily grouped into 3 size-classes: I (from 0.1 to $3 \mathrm{~cm}^{2} ; \mathrm{N}=18$ ), II (from 3.1 to $9 \mathrm{~cm}^{2} ; \mathrm{N}=16$ ) and III $\left(>9.1 \mathrm{~cm}^{2} ; \mathrm{N}=11\right)$. Survival and growth during the last 
2 yr of the study (January 2004 to December 2005) were analyzed separately for each size-class.

Survival was analyzed using the 'life tables' statistics (Fox 1993). Significant differences among size-classes were assessed by 'Comparing Survival in Multiple Groups'. Then, comparison between each pair of sizeclasses was performed using the Gehan'n Wilcoxon test (STATISTICA 6.0 package).

Differences in monthly GRs between size-classes were analyzed by a randomization method based on Manly (1991), since data did not comply with the circularity and homogeneity of the variance-covariance matrix assumptions (as assessed by the Mauchly's sphericity and Box M-tests, respectively). The method consisted of a 2-stage permutation of the data: first, individuals were randomly reassigned to the 3 sizeclasses and then readings for each individual were randomly rearranged among observation times. The whole series of data was randomized 4999 times (plus the observed 1) to approximate the null hypothesis distribution of the sum of squares for each factor and their interaction, and then we examined how extreme the observed values were in this distribution. An effect was judged significant when the observed sum of squares was exceeded by less than $5 \%$ of the corresponding values in the randomization series. A modified version of the Turbopascal program by Turon et al. (1998) was applied to perform the permutation tests.

Cross-correlation analysis (using the Pearson coefficient) was performed to check for relationships between monthly GRs and temperature (STATISTICA 6.0 package).

Significant differences in CRs for each picoplankton type in each season were analyzed by 1-way ANOVA. The Tukey test was used for a posteriori pair comparisons. Data fulfilled the normality and homogeneity assumptions as tested by Kolmogorov-Smirnov and Bartlett tests, respectively.

\section{RESULTS}

\section{Growth dynamics}

The time course of the monthly GR of Corticium candelabrum during more than 3 yr (September of 2002 to December of 2005) is depicted in Fig. 1. The GRs are presented separately for 2003 and 2004 to 2005 due to a massive mortality event that occurred after summer 2003 and obligated us to add new individuals to the survey. Water temperature at the study site along the monitoring period is also included in the graph.

A seasonal trend in GRs was observed, although growth had slightly different trends depending on the year. GRs peaked in June to July 2003 (summer) while

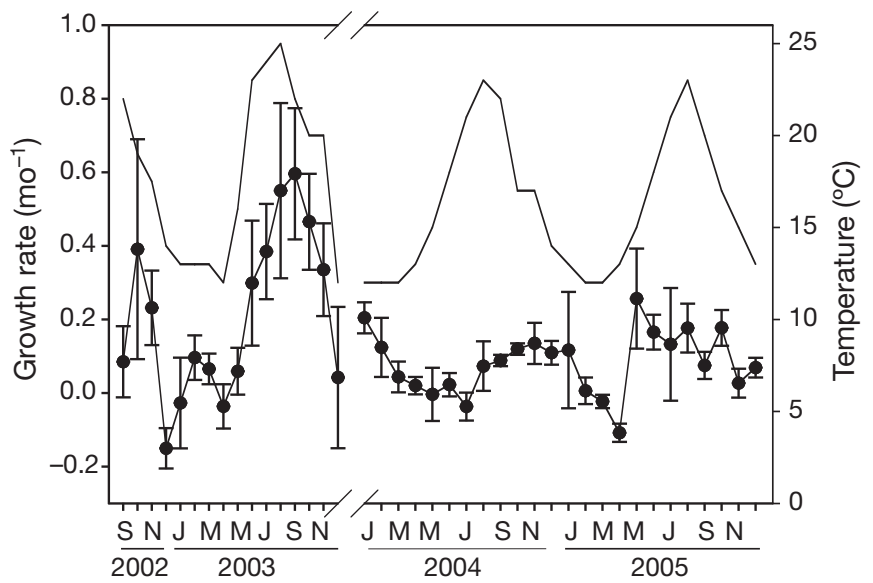

Fig. 1. Corticium candelabrum. Time course of the monthly mean $( \pm \mathrm{SE})$ growth rate and water temperature $\left({ }^{\circ} \mathrm{C}\right)$ at the study site. The graph is broken to indicate the inclusion of new individuals to replace those lost at the end of 2003 due to a drastic mortality event

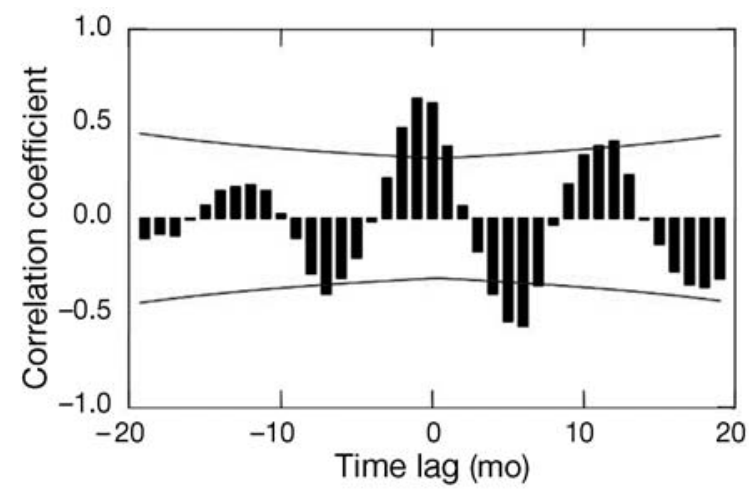

Fig. 2. Corticium candelabrum. Cross-correlation analyses of growth rates and temperature

maximal GRs were recorded in October to November of 2004 (autumn) and in May 2005 (spring). In general, GRs started to decrease at the end of autumn, the lowest in winter during the $3 \mathrm{yr}$ of study. GRs are positively correlated with temperature at time lags of $-2,-1,0$, and 1 mo (cross correlation analysis) (Fig. 2).

The maximum monthly GR computed during the $3 \mathrm{yr}$ was $0.55 \pm 0.24$ (mean $\pm \mathrm{SE}$ ) and was recorded in August 2003 in accordance with the highest temperature. The average monthly GR for the 3 yr study period was $0.19 \pm 0.02$ (mean $\pm \mathrm{SE})$.

Negative average GRs (shrinkage rates) occurred only once or twice per year, generally in winter but also in spring (2003 and 2004). The maximum monthly shrinkage rate observed was $-0.15 \pm 0.05($ mean $\pm \mathrm{SE}$ ) and was recorded in December 2003. The mean monthly shrinkage rate for the $3 \mathrm{yr}$ was $-0.06 \pm 0.02$ (mean $\pm \mathrm{SE})$. 
Variability in GRs was high among individuals likely due to a size effect (i.e. differential GRs according to sponge size).

The life dynamics of Corticium candelabrum included fission and fusion events at relatively low frequencies. Fission events occurred in 6 out of 39 mo monitored, mainly in summer and occasionally in winter. Only 1 or 2 fission events per month were recorded, except in August 2003 when 12 fissions took place in the same individual. Only 1 fusion event occurred during the 3 yr of study (August 2003).

Predation events occurred throughout the year, especially concentrated in summer. Sponge predation was observed in 9 out of the 38 mo of study, in which 2 to $7 \%$ of the sponge individuals monitored were predated to some extent. The nudibranchia Platydoris argo was the only predator observed, but other potential predators cannot be discarded.
Regeneration of damaged-after-predation individuals was also recorded by observing the recovery of the orangy-brown pigmentation typical of the sponge cortex. Forty percent of the predated individuals totally recovered the original shape (Fig. 3), and $40 \%$ partially recovered the damaged area with a subsequent decrease in size. On the other hand, in $13 \%$ of the cases, the area damaged was so large that the individual fissioned into several small sponges (Fig. 4). Finally, 7 \% of the predated sponges died. The recovery process usually took ca. $1 \mathrm{mo}$, and when the specimens experienced strong damage, the process took 2 to 3 mo. Regeneration rates were calculated for those individuals that recovered totally or partially (i.e. $80 \%$ ). Mean regeneration rates were $0.45 \pm 0.12$ (mean $\pm \mathrm{SE})$, significantly higher than mean GRs ( $\mathrm{p}<0.05$, Student's $t$-test).

The cumulative survival function of Corticium candelabrum during the study period is depicted in Fig. 5.
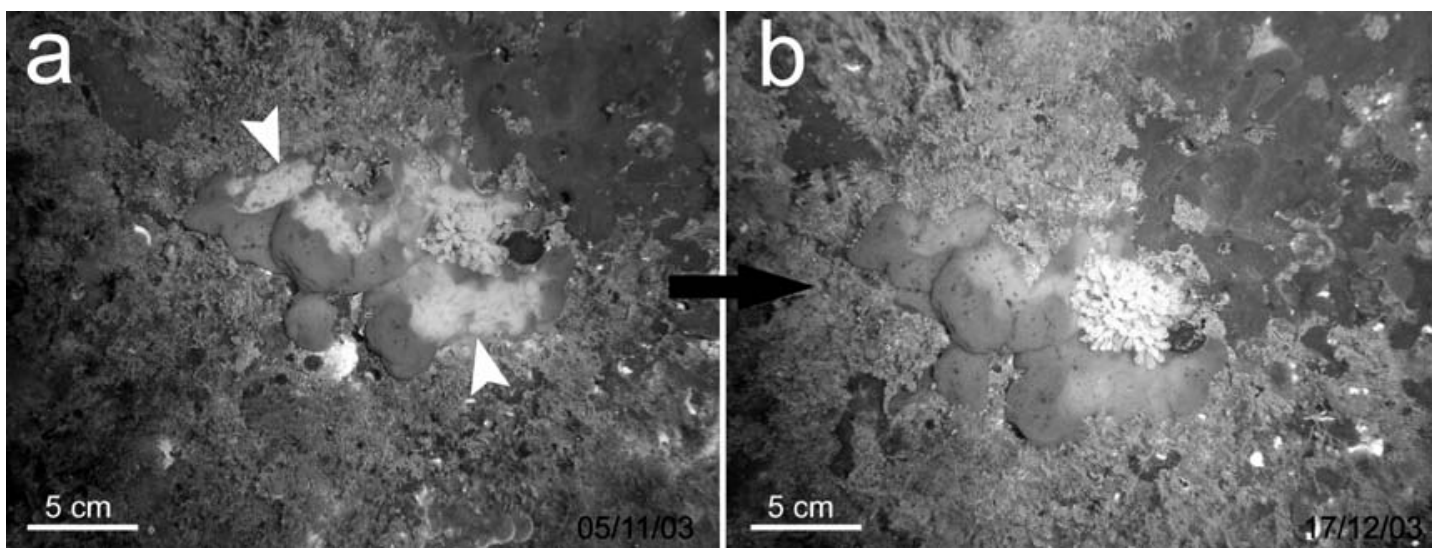

Fig. 3. Corticium candelabrum. Instance of regeneration after 1 mo. (a) Individual partially damaged (white areas, arrowheads) in November 2004 and (b) the same individual almost totally recovered (typically orangy-brown in color) 1 mo later
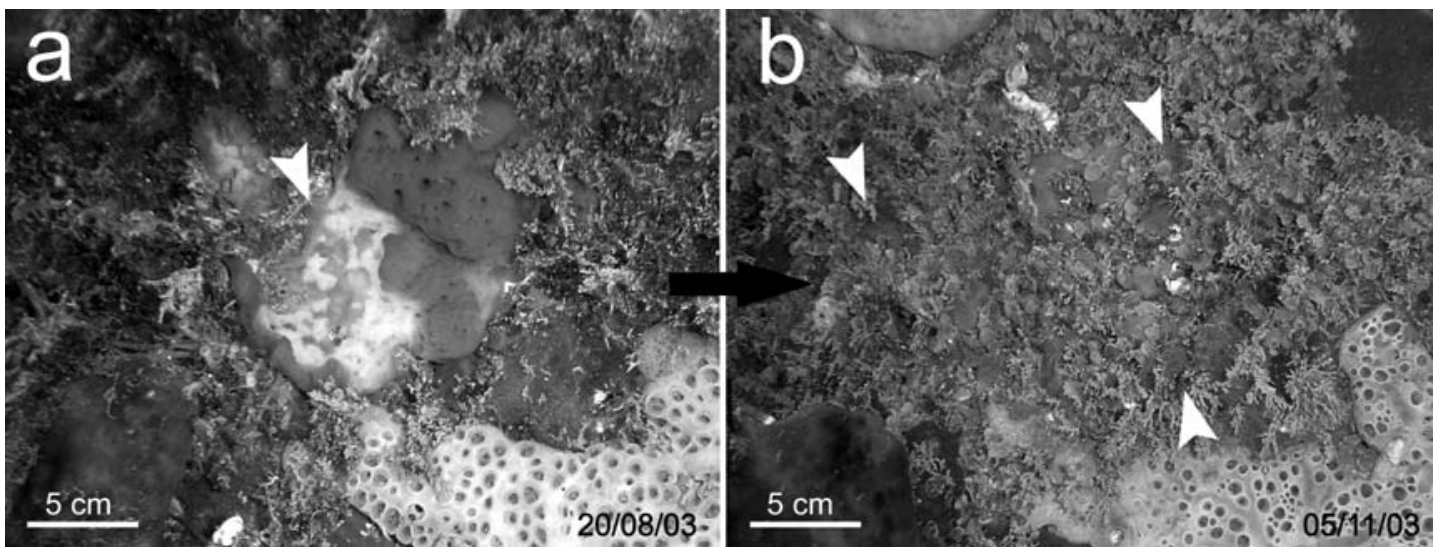

Fig. 4. Corticium candelabrum. Fission event in a previously damaged individual. (a) Damaged (white area, arrowhead) individual and (b) individuals resulting from the fission event 3 mo later (arrowheads) 


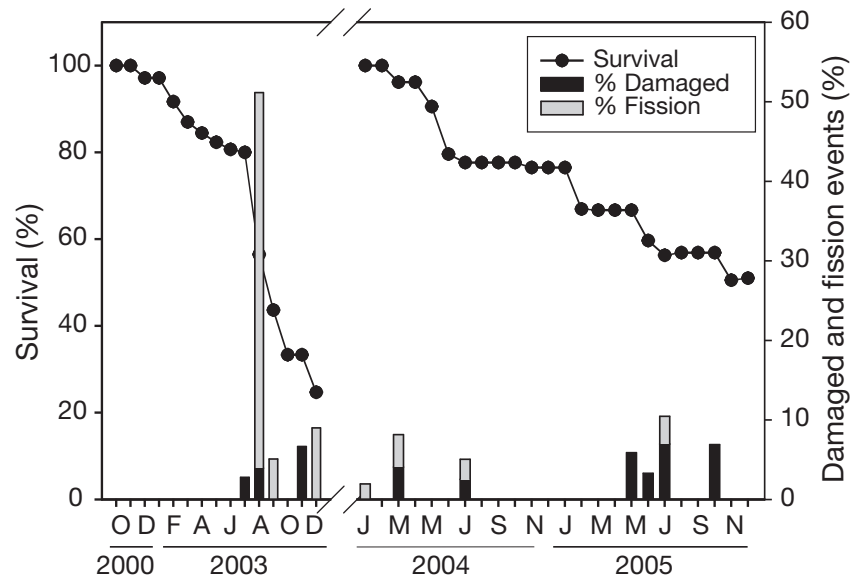

Fig. 5. Corticium candelabrum. Cumulative survival profile during the $3 \mathrm{yr}$ of monitoring (2002 to 2005). Stacked bars indicate the percentage of damaged and fissioned individuals at each month. The graph is broken to indicate the inclusion of new individuals to replace those lost at the end of 2003 due to a drastic mortality event

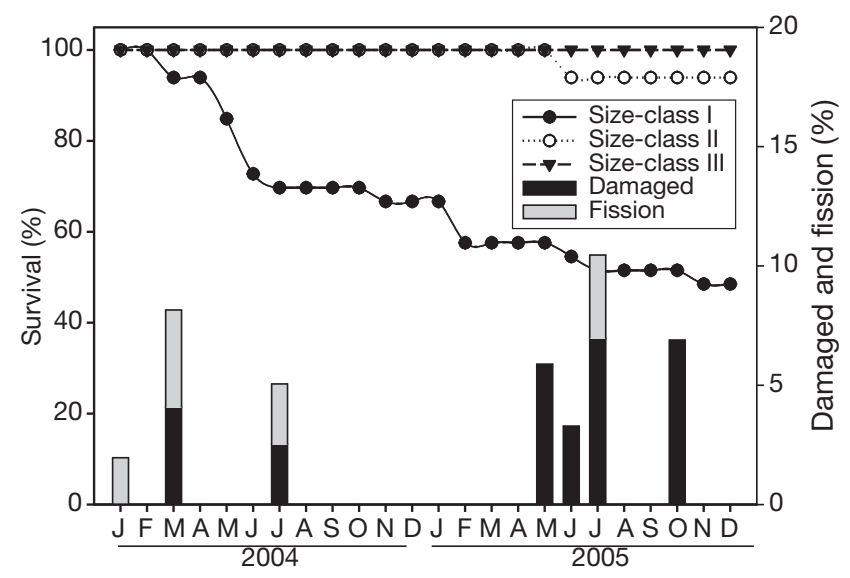

Fig. 6. Corticium candelabrum. Cumulative survival profiles for each of the 3 size-classes for 2004 and 2005. Stacked bars indicate the percentage of damaged and fissioned individuals at each month

During 2003 survival decreased drastically in summer-autumn, ranging from $80 \%$ in July to ca. $24 \%$ in December. During 2004 and 2005 a stepped survival profile was observed, with several consecutive months without mortality separated by shorter mortality events mainly occurring in cold periods (i.e. winter-spring).

The sponges monitored during the last $2 \mathrm{yr}$ were separated into 3 size-classes (see 'Materials and methods') and each size-class was analyzed separately. Survival was significantly different for the 3 size-classes ( $p<0.001$, comparing multiple samples), being significantly lower for the smallest individuals (i.e. size-class I) (p $<0.05$ between size-classes I and II and $p<0.005$ between size-classes I and III, Gehan's Wilcoxon test)

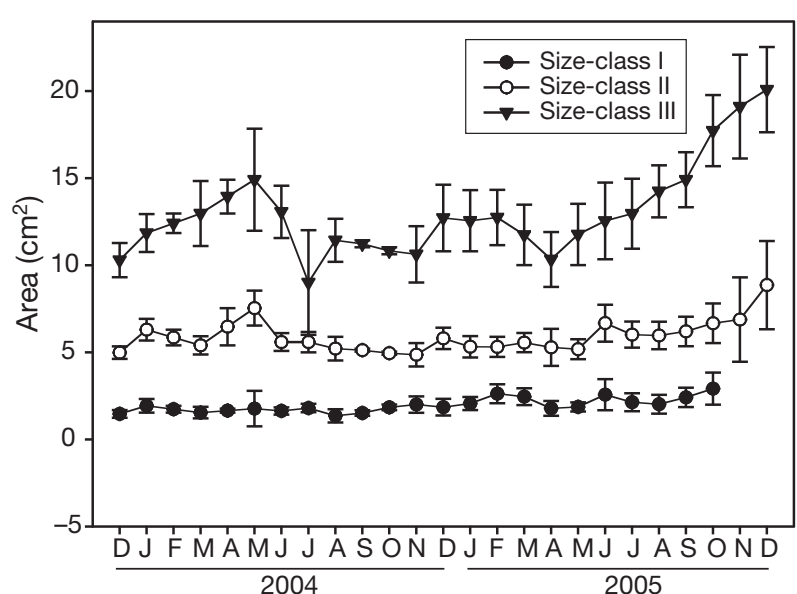

Fig. 7. Corticium candelabrum. Time course of the monthly mean $( \pm \mathrm{SE})$ area $\left(\mathrm{cm}^{2}\right)$ of the 3 size-classes from December 2003 to December 2005

than for medium and large individuals (size-classes II and III), which survived the same $(p=0.6$, Gehan's Wilcoxon test) (Fig. 6).

Time course of the mean monthly area is represented in Fig. 7 for the 3 size-classes separately. For size-class I the sponge mean area at the end of the monitoring ( $2 \mathrm{yr}$ ) increased from $1.462 \pm 0.222$ to $2.911 \pm 0.921 \mathrm{~cm}^{2}$ (mean $\pm \mathrm{SE}$ ). For size-class II sponge mean area increased from $4.983 \pm 0.358$ to $8.859 \pm 2.532 \mathrm{~cm}^{2}$ $($ mean $\pm \mathrm{SE})$, and for the size-class III the final mean area was almost twice the initial area (from $10.293 \pm$ 0.984 to $20.08 \pm 2.447 \mathrm{~cm}^{2}$, mean $\pm \mathrm{SE}$ ). Differences in GRs among size-classes were significant $(p<0.01$, permutation test). The a posteriori pair comparisons showed (after Bonferroni's correction) that the smaller individuals presented significantly higher GRs than the other 2 size-classes $(\mathrm{p}<0.01$ between size-classes I and II and $\mathrm{p}<0.005$ between size-classes I and III, permutation test); no significant differences were found between size-class II and III ( $\mathrm{p}=0.8$, permutation test).

Survival and mean GRs for the 3 size-classes are depicted in Fig. 8 where it is shown that size-class I had the lowest survival and the highest GR.

\section{Filtration experiments}

Our results showed that the concentration of potential food particles at the study site varied quantitatively and qualitatively throughout the year (Table 1). The heterotrophic bacteria and the picoeukaryotes were present all the year round; conversely Synechococcus sp. was more abundant in summer and disappeared in spring; Prochlorococcus sp. was present only from autumn to winter. 


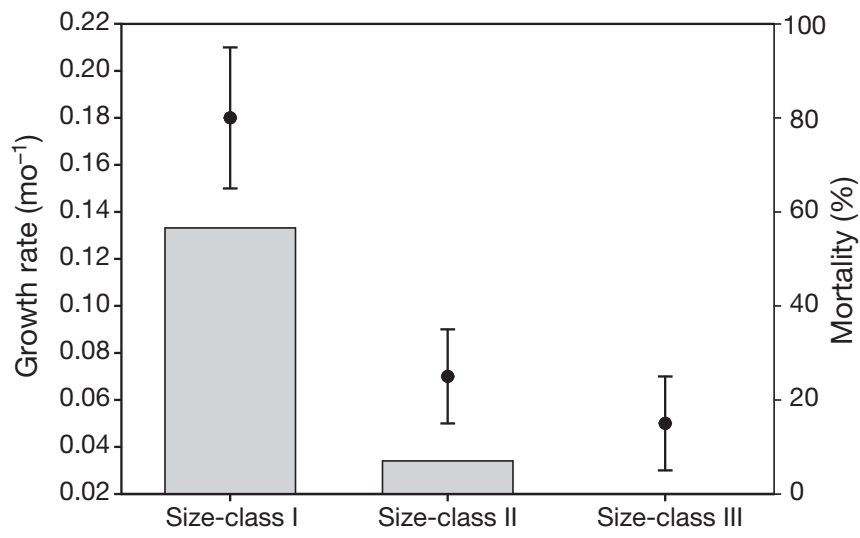

Fig. 8. Corticium candelabrum. The 2 yr (since January 2004) growth rate mean $( \pm \mathrm{SE})$ for the 3 size-classes. Grey bars indicate cumulative mortality after $2 \mathrm{yr}$ for the 3 size-classes

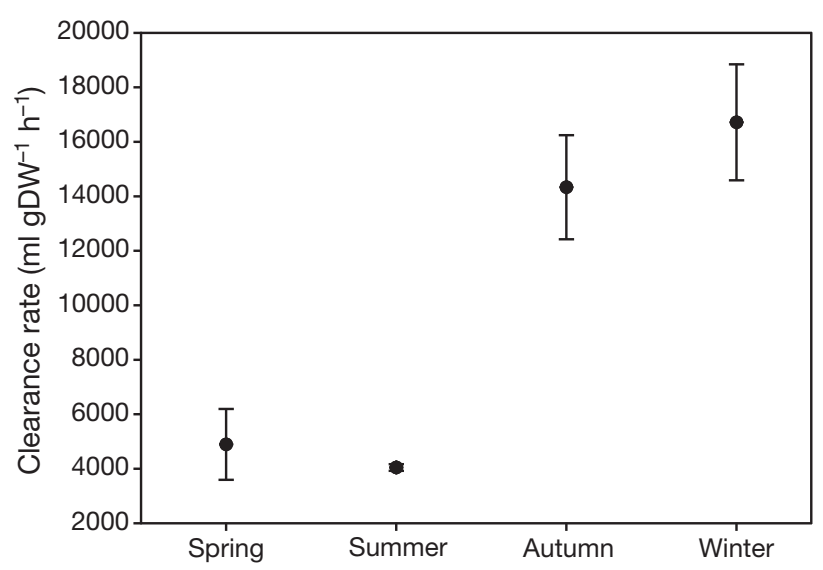

Fig. 9. Corticium candelabrum. Mean $( \pm \mathrm{SE})$ total clearance rates per season

The diet of Corticium candelabrum was highly heterogeneous according to the seasonal variation of picoplankton abundance in the water. The total CRs (all the food particles considered) varied significantly with the season $(p<0.05$, ANOVA). CRs were similar in spring and summer and also in autumn and winter $(p>$ 0.6 for both comparisons, Tukey test), being higher in autumn-winter than in springsummer $(\mathrm{p}<0.05$ for all comparisons, Tukey test) (Fig. 9).

Differences in CRs for each picoplankton type with season indicated that the sponge retained, with different efficiency, the several food particles present in the water (assuming that water transport was constant, see 'Materials and methods'), especially Prochlorococcus sp. (Fig. 10). In

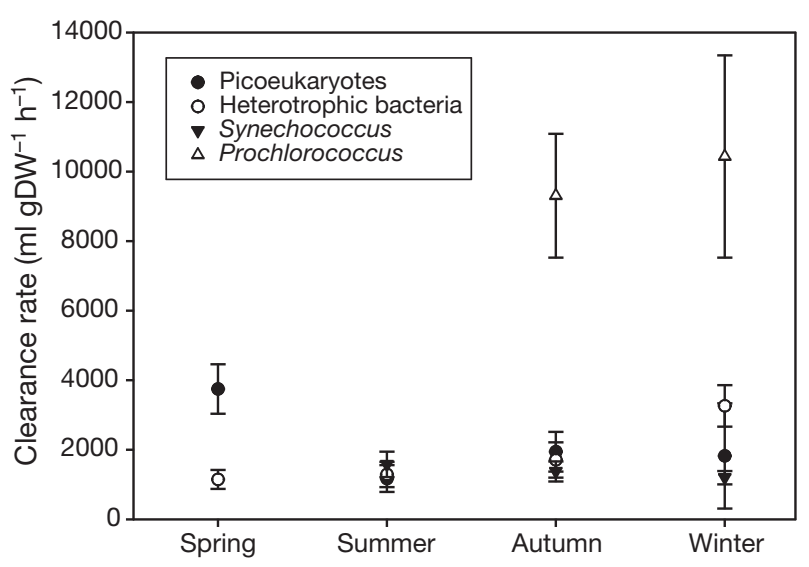

Fig. 10. Corticium candelabrum. Mean $( \pm \mathrm{SE})$ clearance rate for each picoplankton type per season

spring, when picoplankton consisted only of picoeukaryotes and heterotrophic bacteria, picoeukaryotes were significantly more retained than bacteria $(76.5 \%$ and $23.5 \%$ respectively; $p<0.05$, Tukey test). In summer, when Synechococcus sp. was present, no significant differences ( $p=0.75$, ANOVA $)$ in CRs were observed for the several food particles present $(29 \%$, $31.9 \%$ and $39.1 \%$ for picoeukaryotes, heterotrophic bacteria and Synechococcus sp, respectively). In autumn, when Prochlorococcus sp. was present at high densities, the 4 picoplankton types were differently retained ( $p<0.05$, ANOVA), with Prochlorococcus sp. uptake significantly higher $(64.9 \%, \mathrm{p}<0.05$, Tukey test, for the 3 comparisons). Conversely, no significant differences $(p>0.05)$ were found among the other picoplankton types (13.6, 11.9 and $9.6 \%$ for picoeukaryotes, heterotrophic bacteria and Synechococcus sp. respectively). In winter, Prochlorococcus sp. was also abundant, and the 4 picoplankton types were also differently retained ( $p<0.05$, ANOVA). Prochlorococcus sp. uptake was significantly higher $(62.4 \%, \mathrm{p}<0.05)$ than the other 3 picoplankton types, which were retained similarly $(10.9,19.5$ and $7.2 \%$ of picoeukaryotes, heterotrophic bacteria and Synechococcus sp., respectively, $\mathrm{p}>0.05$ for all comparisons).

Table 1. Concentration $\left(10^{3}\right.$ cells $\left.\mathrm{ml}^{-1}\right)$ of the different picoplankton groups at the study site in each season (mean $\pm \mathrm{SE}$ ). - : concentrations under detection level

\begin{tabular}{|lcccc|}
\hline & $\begin{array}{c}\text { Prochloro- } \\
\text { coccus }\end{array}$ & $\begin{array}{c}\text { Synecho- } \\
\text { coccus }\end{array}$ & $\begin{array}{c}\text { Heterotrophic } \\
\text { bacteria }\end{array}$ & Picoeukaryotes \\
\hline Spring & - & - & $1180 \pm 340$ & $2.81 \pm 0.93$ \\
Summer & - & $129 \pm 45$ & $2450 \pm 600$ & $2.10 \pm 1.34$ \\
Autumn & $17.7 \pm 8.1$ & $24.2 \pm 14.4$ & $870 \pm 480$ & $8.52 \pm 2.55$ \\
Winter & $9.99 \pm 2.11$ & $6.05 \pm 2.32$ & $943 \pm 180$ & $3.67 \pm 1.51$ \\
\hline
\end{tabular}




\section{DISCUSSION}

As more study cases are incorporated into the body of knowledge of sponge growth in temperate environments, a general pattern becomes evident. The extraordinarily slow GRs found for Corticium candelabrum during the last $2 \mathrm{yr}$ of the present study are in accordance with those reported for other temperate encrusting sponges (i.e. Ayling 1983, Pansini \& Pronzato 1990, Turon et al. 1998, Garrabou \& Zabala 2001, Tanaka 2002). However, inter-annual differences in GRs can be occasionally high, as is shown by comparing GRs of the first year of the present study with those following. The mean size of the monitored individuals, which was smaller than those of the second and third years, might account for these differences, since small individuals seemed to grow faster. However, particular environmental conditions in a given year, such as the high temperature registered in 2003, might also exert an effect by increasing the sponge metabolism, although these high temperatures may also be detrimental for sponge survival (see Fig. 5).

The generally slow growth contrasts with the quite fast RRs that sponges show after damage. Corticium candelabrum regenerates 2.4 times faster than it grows, a similar ratio to those reported for other species (e.g. Leys \& Lauzon 1998, Turon et al. 1998) but lower than the extraordinarily higher rates reported in other sponge species (e.g. 10 and up to 2900 times natural GRs in Neofibularia nolitangere and Eurypon sp., respectively) (Hoppe 1988 and Ayling 1983, respectively).

Seasonal growth dynamics similar to those of Corticium candelabrum, with the highest GRs in springsummer, have also been reported for other temperate sponges (e.g. Johnson 1979, Turon et al. 1998, Garrabou \& Zabala 2001, Tanaka 2002).

When we analyzed the monitored sponges in 3 separate size-classes, the smallest individuals showed the highest GRs, while no differences between the other 2 size-classes (medium and large sizes) were found. A different GR as a function of sponge size was also recorded for Crambe crambe (Turon et al. 1998) and Halichondria panicea (Barthel 1989), with younger individuals growing faster than older individuals. This behavior of Corticium candelabrum could be related to the necessary investment in sexual reproduction at the expense of somatic growth, which takes place in medium and large individuals but does not occur in small ones (S. De Caralt \& M. J. Uriz pers. obs.), as has been reported for other sponge species (e.g. C. crambe, Uriz et al. 1995, and Scopalina lophyropoda, Blanquer 2007).

The fission events that have been often reported in sponges (e.g. Elvin 1976, Johnson 1979) may have relevance at a population level by contributing to clonality in the sponge population (Duran et al. 2004). In Corticium candelabrum, however, fissions are less frequent than in other sponges (e.g. Scopalina lophyropoda, Blanquer 2007), and they mainly resulted $(80.5 \%)$ from previous serious damage. The elimination of the damaged tissue and the regeneration process of the resulting fragments end in several smaller specimens able to survive and grow and eventually to fuse. Thus, fissions appear to be a way to overcome negative interactions with competitors or predators, and thus they may represent a survival strategy closely related to the reported partial mortality in clonal invertebrates (Turon 1992).

Survival of Corticium candelabrum takes place in a stepped fashion with long periods of stability followed by some mortality in cold months (winter-spring), when sponge GRs were the lowest. When the monitored sponges were separated into 3 size-classes, it was shown that mortality prevailed among the small individuals. Turon et al. (1998) found a significant negative relationship between mortality and size in Crambe crambe. Garrabou \& Zabala (2001) also indicated that the mortality events observed during their 3 yr monitoring of $C$. crambe were exclusively experienced by the smallest specimens. These results altogether suggest that sponges need to reach a given size patch (size refuge) beyond which mortality decreases considerably.

However, although regular mortality of Corticium candelabrum mainly occurs in cold months (winterspring), massive mortality events may take place sporadically due to external perturbations, as occurred at the end of 2003 when $80 \%$ of the monitored individuals died after an extremely warm summer. In June 2003, water temperatures increased from 16 to $22^{\circ} \mathrm{C}$ and remained abnormally high all summer $\left(25^{\circ} \mathrm{C}\right.$ at $10 \mathrm{~m}$ in August). Massive mortality events of sponges and gorgonians, which were attributed to unusually high temperatures related to the western Mediterranean warming (e.g. Bethoux et al. 1990), have been repeatedly reported in the western Mediterranean (Cerrano et al. 2000, Perez et al. 2000, Romano et al. 2000).

Corticium candelabrum shows relatively high CRs (compared with those of other Mediterranean species studied (Dysidea avara, Turon et al. 1997, Ribes et al. 1999). In particular, the CRs on Prochlorococcus sp. are 2 times higher than those reported for D. avara (Turon et al. 1997, Ribes et al. 1999). Prochlorococcus sp. is the food particle most efficiently retained by $C$. candelabrum in our in situ experiments, which might be due to an optimal food particle size (e.g. Ribes et al. 1999, Turon et al. 1998). C. candelabrum cleared the water from picoplankton at the lowest rates in late spring- 
summer, when it showed the highest growth. This, at a first glance, contradictory relationship may be explained by the reduction of the number of functional pumping units due to the reproduction process, which occurs in spring-summer and involves transformation of choanocyte chambers into spermatogonia (e.g. De Caralt et al. 2007). Later on during development, embryos occupy an important part of the sponge choanosome (e.g. Uriz et al. 1998), which also may result in a lower pumping capacity.

To summarize, the growth of Corticium candelabrum recorded confirms the general reputation of sponges as slow-growing animals. However, it also shows a great dynamism (i.e. RRs, fission events), which may have contributed to the great success experienced by sponges in benthic ecosystems since the Palaeozoic. Sponges have successfully inhabited the oceans since the Precambrian (e.g. Pisera 2006) thanks to their enormous plasticity and dynamics, which allow them to adapt to environmental changes without changing fundamental features.

Acknowledgements. This study was partially funded by projects INTERGEN CICYT: CTM2004-05265-C02-02/MAR and SPONGES (European Commission): 017800. We thank E. Cebrian, A. Blanquer and R. Martí for helping with monitoring and experimentation at sea and $\mathrm{M}$. Ribes for her help with the flow cytometer. We also thank X. Turon for facilitating the statistical program to perform the permutation tests.

\section{LITERATURE CITED}

Ayling AC (1983) Growth rates and regeneration in thinly encrusting demospongiae from temperate waters. Biol Bull 165:343-352

Barthel D (1989) Growth of the sponge Halichondria panicea in the north sea habitat. In: Polish Academy of Sciences Institute of Oceanology (ed) Proc 21st EMBS, Gdansk, 14-19 Sep. Polish Academy of Sciences, Sopot

Bethoux JP, Gentili B, Raunet J, Tailliez D (1990) Warming trend in the western Mediterranean deep water. Nature 347:660-662

Blanquer A (2007) Molecular markers for phylogenetic and population studies of the genus Scopalina (Porifera: Demospongiae). PhD thesis, Barcelona University

Cebrian E, Martí R, Agell G, Uriz MJ (2006) Response of the Mediterranean sponge Chondrosia reniformis Nardo to heavy metal pollution. Environ Pollut 141:452-458

> Cerrano C, Bavestrello G, Bianchi CN, Cattaneo-vietti R and others (2000) A catastrophic mass-mortality episode of gorgonians and other organisms in the Ligurian Sea (northwestern Mediterranean), summer 1999. Ecol Lett 3: 284-293

> De Caralt S, Agell G, Uriz MJ (2003) Long-term culture of sponge explants: conditions enhancing survival and growth and assessment of bioactivity. Biomol Eng 20: 339-347

> De Caralt S, Uriz MJ, Ereskovsky AV, Wijffels R (2007) Embryo development of Corticium candelabrum (Demospongiae: Homosclerophorida). Invertebr Biol 126: 211-219
Duckworth AR, Batershill CN (2001) Population dynamics and chemical ecology of New Zealand Demospongiae Latrunculia sp. nov. and Polymastia croceus (Poecilosclerida: Latrunculiidae: Polymastiidae). N Z J Mar Freshw Res 35:935-949

Duran S, Pascual M, Estoup A, Turon X (2004) Strong population structure in the marine sponge Crambe crambe (Poecilosclerida) as revealed by microsatellite markers. Mol Ecol 13:511-522

Elvin DW (1976) Seasonal growth and reproduction of an intertidal sponge Haliclona permollis (Bowerbank). Biol Bull 151:108-125

Fox GA (1993) Failure-time analysis: emergence, flowering, survivorship and other waiting times. In: Scheiner SM, Gurevitch J (eds) Design and analysis of ecological experiments. Chapman \& Hall, London, p 113-137

Garrabou J, Zabala M (2001) Growth dynamics in four Mediterranean demosponges. Estuar Coast Shelf Sci 52: 293-303

> Gasol JM, Morán XAG (1999) Effects of filtration on bacterial activity and picoplankton community structure as assessed by flow cytometry. Aquat Microb Ecol 16:251-264

> Henry LA, Hart M (2005) Regeneration from injury and resource allocation in sponges and corals - a review. Int Rev Hydrobiol 90:125-158

Hoppe WF (1988) Growth, regeneration and predation in three species of large coral reef sponges. Mar Ecol Prog Ser 50:117-125

Jackson JBC, Palumbi SR (1979) Regeneration and partial predation in cryptic coral reef environments: preliminary experiments on sponges and ectoprocts. In: Lévi C, BouryEsnault N (eds) Biologie des spongiaires. Publications du CNRS, Paris, p 303-308

Johnson MF (1979) Recruitment, growth, mortality and seasonal variations in the calcareous sponge Clathrina coriacea (Montagu) and C. blanca (Miklucho-Maclay) from Santa Catalina Island, California. In: Lévi C, BouryEsnault N (eds) Colloques Internacionaux du CNRS, 291. Publications du CNRS, Paris, p 325-334

Leys SP, Lauzon NRJ (1998) Hexactinellid sponge ecology: growth rates and seasonality in deep water sponges. J Exp Mar Biol Ecol 230:111-129

Manly FJ (1991). Randomization and monte carlo methods in biology. Chapman \& Hall, London

Margalef R (1985) Key environments: western Mediterranean. Pergamon Press, Oxford

Pansini M, Pronzato R (1990) Observations on the dynamics of a Mediterranean sponge community. In: Rützler K (ed) New perspectives in sponge biology. Smithsonian, Institution Press, Washington, DC, p 404-415

Perez T, Garrabou J, Sartoretto S, Harmelin JG, Francour P, Vacelet J (2000) Mass mortality of marine invertebrates: an unprecedented event in the NW Mediterranean. C R Acad Sci III 323:853-865

Petersen JK, Riisgård HU (1992) Filtration capacity of the ascidian Ciona intestinalis and its grazing impact in a shallow fjord. Mar Ecol Prog Ser 88:9-17

Pisera A (2006) Palaeontology of sponges-a review. Can J Zool 84:242-261

Reiswig HM (1971) Particle feeding in natural populations of three marine demosponges. Biol Bull 141:568-591

Ribes M, Coma R, Gili MJ (1999) Seasonal variation of particulate organic carbon, dissolved organic carbon and the contribution of microbial communities to the live particulate organic carbon in a shallow near-bottom ecosystem at the northwestern Mediterranean Sea. J Plankton Res 21: $1077-1100$ 
Romano JC, Bensoussan N, Younes WAN, Arlhac D (2000) Anomalies thermiques dans les eaux du golfe de Marseille Durant l'été 1999. Une explication partielle de la mortalité d'invertébrés fixés. C R Acad Sci III 323:415-427

Sebens KP (1987) The ecology of intermediate growth in animals. Annu Rev Ecol Syst 18:371-407

Sipkema D, Yosef NAM, Adamczewski M, Osinga R, Mendola D, Tramper J, Wijffels RH (2006) Hypothesized kinetic models for describing the growth of globular and encrusting demosponges. Mar Biotechnol 8:40-51

Stocker LJ (1991) Effects of size and shape of colony on rates of fusion, growth and mortality in a subtidal invertebrate. J Exp Mar Biol Ecol 149:161-175

Tanaka K (2002) Growth dynamics and mortality of the intertidal encrusting sponge Halichondria okadai (Demospongiae, Halichondrida). Mar Biol 140:383-389

Turon X (1992) Periods of non-feeding in Polysyncraton lacazei (Ascidiacea: Didemnidae): a rejuvenative process? Mar Biol 112:647-655

Turon X, Galera J, Uriz MJ (1997) Clearance rates and aquiferous systems in two sponges with contrasting life history

Initial editorial responsibility: Howard Browman, Storebø, Norway (until November 5, 2007); Final editorial responsibility: Matthias Seaman, Oldendorf/Luhe, Germany strategies. J Exp Zool 278:22-36

> Turon X, Tarjuelo I, Uriz MJ (1998) Growth dynamics and mortality of the encrusting sponge Crambe crambe (Poecilosclerida) in contrasting habitats: correlation with population structure and investment in defense. Funct Ecol 12: 631-639

Uriz MJ, Rosell D, Martín D (1992) The sponge population of the Cabrera archipelago (Balearic Islands): characteristics, distribution and abundance of the most representative species. PSZN I: Mar Ecol 113:101-117

Uriz MJ, Turon X, Becerro MA, Galera J, Lozano J (1995) Patterns of resource allocation to somatic, defensive and reproductive functions in the Mediterranean encrusting sponge Crambe crambe (Demospongiae, Poecilosclerida). Mar Ecol Prog Ser 124:159-170

> Uriz MJ, Maldonado M, Turon X, Martí R (1998) How do reproductive output, larval behavior and recruitment contribute to adult spatial patterns in Mediterranean encrusting sponges? Mar Ecol Prog Ser 167:137-148

> Wulff JL (2006) Resistance versus recovery: morphological strategies of coral reef sponges. Funct Ecol 20:699-708

Submitted: July 2, 2007; Accepted: December 3, 2007

Proofs received from author(s): April 30, 2008 